\title{
Comparison of recovery rate in acute rinopharyngitis after antibiotic and non antibiotic treatment
}

\author{
Beta Andewi Resti Anggraheni ${ }^{*}$, Wahyudi Istiono ${ }^{2}$ \\ 'Panembahan Senopati District Hospital, Bantul District, Yogyakarta Special Region, \\ 2Department of Public Health, Faculty of Medicine, Universitas Gadjah Mada, Yogyakarta, \\ Indonesia
}

\begin{abstract}
Acute rhinopharyngitis (ARI) remains become a major public health problem in the world. About 2.3 million people are diagnosed with ARI annually. In Cilacap District of Central Java, approximately 350 patients visit primary health care center due to URTI symptoms monthly. Acute rhinopharyngitis is commonly caused by viruses, therefore the use of antibiotics is not recommended. However, many evidences showed that antibiotics are prescribed to treat ARI. The aim of this study is to compare of recovery rate in acute rinopharyngitis after antibiotic and non antibiotic treatment. This was a double-blind randomized controlled trial study involving ARIs patients who visited primary health care center (Puskesmas) of Cilacap I, Cilacap District. The patients who met the inclusion and exclusion criteria were recruted and divided into two groups i.e. Treatment Group and Control Group. The Treatment Group was given symptomatic drugs and amoxicillin $500 \mathrm{mg}$ three time daily for five days, while the Control Group was just given symptomatic drugs. The recovery rate of $A R I$ patients was evaluated on the fifth day after drugs administration. One hundred and sixty six eligible ARI patients consisting 83 patients of each group were involved in this study. The results showed that the recovery rate in the Treatment Group (57 patients or $68.7 \%$ ) was not significantly different with the Control Group (51 patients or $61.7 \%)(p=0.417)$. Moreover, age, gender difference, smoking activity did not influence the recovery rate of ARI patients. However, occupation category influenced the recovery rate. In conclusion, the administration of antibiotic in ARI patients does not influence their recovery rate.
\end{abstract}

\section{ABSTRAK}

Rinofaringitis akut masih tetap menjadi masalah kesehatan masyarakat di dunia. Sekitar 2,3 juta penduduk dunia didiagnosis rinofaringitis akut setiap tahunnya. Di Kabupaten Cilacap, Jawa Tengah, kurang-lebih 350 penderita berkunjung ke Puskesmas setiap bulan karena rinofaringitis akut. Rinofaringitis akut umumnya disebabkan oleh virs, sehingga penggunaan antibiotik dianjurkan. Namun demikian banyak bukti menunjukkan antibiotik diresepkan untuk mengobati rinofaringitis. Tujuan penelitian ini adalah untuk membandingkan angka kesembuhan penderita rinofaringitis setelah pemberian antibiotik dengan tanpa pemberian antibiotik. Penelitian ini merupakan penelitian klinik menggunakan rancangan uji terkontrol plasebo secara acak tersamar ganda yang melibatkan penderita rinofaringitis yang berkunjung ke Puskesmas Cilacap I, Kabupaten Cilacap. Penderita yang memenuhi kriteria inklusi dan eksklusi diambil dan dibagi menjadi dua kelompok yaitu Kelompok Perlakuan dan Kelompok Kontrol. Kelompok Perlakuan diberi obat simptomatik dan amoksisilin $500 \mathrm{mg}$, tiga kali sehari selama lima hari, sedangkan Kelompok Kontrol hanya diberi obat simptomatik. Angka kesembuhan penderita rinofaringitis dievaluasi pada hari ke lima setelah pemberian obat. Seratus enam puluh enam penderita rinofaringitis akut yang memenuhi syarat dengan 83 penderita untuk masing-masing kelompok terlibat dalam

\footnotetext{
* corresponding author: beta_semangat@yahoo.com
} 
penelitian ini. Hasil penelitian menunjukkan bahwa angka kesembuhan Kelompok Perlakuan (57 penderita atau $68,7 \%$ ) tidak berbeda bermakna dengan Kelompok Kontrol (51 penderita atau $61,7 \%)(p=0.417)$. Lebih jauh dilaporkan umur, perbedaan jenis kelamin dan aktivitas merokok tidak mempengarhi angka kesembuhan penderita rinofaringitis. Namun tingkat kesembuhan penderita rinofaringitis dipengaruhi oleh jenis pekerjaan. Dari penelitian ini dapat disimpulkan bahwa pemberian antibiotik pada penderita rinofaringitis tidak mempengaruhi angka kesembuhan.

Keywords: acute rinopharyngitis - management - symptomatic drugs - antibiotic - recovery rate

\section{INTRODUCTION}

Acute rhinopharyngitis (ARI) is an acute infection of the upper respiratory tract caused by viral rhinitis. Acute rhinopharyngitis is the most frequent type of upper respiratory tract infections (URTIs) in childhood. Children under five years old may have between five and eight episodes a year. Acute rhinopharyngitis remains become a major public health problems in the world due to in significant morbidity worldwide. ${ }^{1,2}$

In France, it was reported the annual prevalence of symptomatic acute respiratory infections was $27-28 \%$ in a prospective community survey between 2001 and $2002 .{ }^{3}$ In the USA, it was estimated that 7,600 to 48,000 among children under one year old and 8,100 to 42,600 children age one to four years were hospitalized human parainfluenza viruses infection annually. ${ }^{4}$ In Indonesia, 40- 60\% of patients visiting in primary health care center and $15-30 \%$ of outpatients visiting doctors suffer from URTIs. ${ }^{5}$ In Cilacap District of Central Java, approximately 350 patients visit primary health care center due to URTI symptoms monthly. The number of the URTI patients will increase during transition season from wet to dry.

Acute rhinopharyngitis is almost exclusively caused by viruses, such as rhinovirus, coronavirus, respiratory syncytial virus, parainfluenza virus, influenza virus, and coxsackie viruses, adenovirus and some rarer types of viruses. ${ }^{1}$ The use of antibiotic agents are unnecessary to treat ARI due to they do not active against viral infections. In addition, the ARI is a self limiting disease that resolves spontaneously with or without the antibiotics administration. ${ }^{5}$ However, many evidences showed that antibiotics are prescribed regularly by physicians to treat ARI. ${ }^{8-10}$ Unnecessary use of antibiotics in ARI is the main driver for the development of antibiotic resistance. ${ }^{11,12}$

This study was conducted to evaluate the benefic of antibiotic prescreptions in ARIs patients who visited primary health care center (Puskesmas) in Cilacap District, Central Java, Indonesia.

\section{MATERIALS AND METHODS}

\section{Study design}

This study was a double-blind randomized controlled trial involving ARIs patients divided into two groups of patients with antibiotics prescription (Treatment Group) and patients without antibiotic prescriptions (Control Group). The protocol of study has been approved by the Medical and Health Research Ethic Committee, Faculty of Medicine, Universitas Gadjah Mada, Yogyakarta. 


\section{Subjects}

The subjects were selected from ARIs patients who visited Puskesmas of Cilacap I, Cilacap District. The patients who met the inclusion and exclusion criteria were recruted in this study. The inclusion criteria were patients aged over five years who were diagnosed ARIs based on history and physical examination. The exclusion criteria were the patients suffering ARIs more than more than seven days, pregnant women, poor nutrition, using antibiotics during study, and having immunocompromised status. Written informed consent was obtained from all subjects or their parents who agreed to participate in this study.

\section{Protocol of study}

The study was conducted in Puskesmas Cilacap 1, Cilacap District, Central Java from June $17^{\text {th }}$ to July $5^{\text {th }} 2011$. Subjects suspected ARIs underwent anamnesis and clinical examination by physicians of the Puskesmas and were gathered to be selected. An explanation concerning the background, objectives, benefit of the study was given during the selection. The characteristics of subjects who fulfilled the inclusion and exclusion criteria were taken and an informed consent was given to be signed by them self or their parents. Subjects were then randomly allocated into two groups namely group of patients with antibiotics prescription as Treatment Group and group of patients without antibiotic prescriptions as Control Group. The Treatment Group was given symptomatic drugs and amoxicillin $500 \mathrm{mg}$ three time daily for five days, while the Control Group was just given symptomatic drugs. The recovery rate of ARIs was evaluated on the fifth day after drugs administration. ${ }^{13}$

\section{Statistical analysis}

Data were presented as frequency distributions. Chi square $\left(\mathrm{X}^{2}\right)$ test was used to analyze the difference of the recovery rate between the Treatment Group and the Control Group. The $p<0.05$ was considered to be statistically significant for this analysis.

\section{RESULTS}

One hundred and sixty six eligible ARIs patients divided into two groups i.e. Treatment Group (83 patients) and Control Group (83 patients) were involved in this study. The characteristics of subjects are presented in TABLE 1. No significant different in characteristics of subjects includes gender, age, education, occupation and smoking status was observed in both groups. 
TABLE 1. Characteristics of subjects involving in the study

\begin{tabular}{|c|c|c|c|}
\hline Variables & $\begin{array}{l}\text { With antibiotic } \\
\qquad(\mathrm{n}-83)\end{array}$ & $\begin{array}{l}\text { Without antibiotic } \\
\qquad(\mathrm{n}=83)\end{array}$ & $\mathrm{p}$ \\
\hline \multicolumn{4}{|l|}{ Gander } \\
\hline - Male & $43(51.8 \%)$ & $41(49.4 \%)$ & \multirow{2}{*}{0.756} \\
\hline - Women & $40(48.2 \%)$ & $42(50.6 \%)$ & \\
\hline \multicolumn{4}{|l|}{ Age } \\
\hline - Child (5-16) & $16(19.3 \%)$ & $15(18.1 \%)$ & \multirow{4}{*}{0.771} \\
\hline - Adult Children (17-40) & $26(31.3 \%)$ & $32(38.6 \%)$ & \\
\hline - Older adult (41-59) & $29(34.9 \%)$ & $24(28.9 \%)$ & \\
\hline - $\quad$ Eldery $(=60)$ & $12(12.5 \%)$ & $12(14.5 \%)$ & \\
\hline \multicolumn{4}{|l|}{ Education } \\
\hline - Primary School & $26(31.3 \%)$ & $18(21.7 \%)$ & \multirow{5}{*}{0.568} \\
\hline - Junior Hight school & $15(18.1 \%)$ & $16(19.3 \%)$ & \\
\hline - Senior Hight School & $25(30.1 \%)$ & $30(36.1 \%)$ & \\
\hline - Bachelor & $7(8.4 \%)$ & $5(6.0 \%)$ & \\
\hline - Others & $10(8.4 \%)$ & $14(16.9 \%)$ & \\
\hline \multicolumn{4}{|l|}{ Occupation } \\
\hline - Private employer & $15(18.1 \%)$ & $13(15.7 \%)$ & \multirow{5}{*}{0.770} \\
\hline - Farmers/fishing/trade & $6(7.2 \%)$ & $4(4.8 \%)$ & \\
\hline - Workers/builders/ & $16(19.3 \%)$ & $12(14.5 \%)$ & \\
\hline - Not work/ housewife & $25(30.1 \%)$ & $28(33.7 \%)$ & \\
\hline - Others & & & \\
\hline \multicolumn{4}{|l|}{ Smoking } \\
\hline - No smoke, no person in home & $21(25.3 \%)$ & $26(31.3 \%)$ & \multirow{5}{*}{0.064} \\
\hline - No smoke, yes person in home & $33(39.8 \%)$ & $17(20.5 \%)$ & \\
\hline - Smoke 1-9 stam/day & $37(44.6 \%)$ & $45(54.2 \%)$ & \\
\hline - Smoke 10-19 stam/day & $10(12.0 \%)$ & $13(15.7 \%)$ & \\
\hline - Smoke $>20$ stam/day & $3(3.6 \%)$ & $7(8.4 \%)$ & \\
\hline
\end{tabular}

TABLE 2 Shows the comparison of recovery rate of patients after antibiotic and non antibiotic treatment. No significant different in the recovery rate of patients was observed in both of grops $(\mathrm{p}=0.416)$.

TABLE 2. Comparison of recovery rate of patients after antibiotic with non antibiotic treatment

\begin{tabular}{lrcc}
\hline Variables & Recover (n 83) & Non-recover (n 83) & \multicolumn{1}{c}{$p$} \\
\hline Antibiotic & $57(68.7 \%)$ & $26(31.7 \%)$ & 0.416 \\
Non antibiotic & $51(61.4 \%)$ & $32(38.6 \%)$ & \\
\hline
\end{tabular}

TABLE 3 shows the comparison of recovery rate of patients based on gender differences. The recovery rate of male patients was not significantly different compared to female patients $(p=0.628)$. 
TABLE 3. Comparison of recovery rate based on gender differences

\begin{tabular}{lccc}
\hline \multicolumn{1}{c}{ Variables } & Recover $(\mathrm{n}=83)$ & Non-recover $(\mathrm{n}=83)$ & $\mathrm{p}$ \\
\hline Male & $53(63.1 \%)$ & $31(36.9 \%)$ & 0.628 \\
Female & $55(67.1 \%)$ & $27(32.9 \%)$ & \\
\hline
\end{tabular}

TABLE 4 shows the comparison of recovery rate of patients based on their age. No significant different was observed in the recovery rate of children, yong adult, adult and geriatric patients $(p=0.136)$.

TABLE 4. Comparison of recovery rate based on age of patients

\begin{tabular}{lccc}
\hline Variables & Recover $(\mathrm{n}-83)$ & Non-recover $(\mathrm{n}-83)$ & $\mathrm{p}$ \\
\hline Children & $22(71.0 \%)$ & $9(29.0 \%)$ & \\
Young adult & $43(74.1 \%)$ & $15(25.9 \%)$ & \\
Adult & $29(54.7 \%)$ & $24(45.3 \%)$ & 0.136 \\
Geriatry & $14(58.3 \%)$ & $10(41.7 \%)$ & \\
\hline
\end{tabular}

TABLE 5 shows the compariosn of recovery rate of patients based on their occupations. A significant different was observed in the recovery rate of who work as public/private employees, farmer/sailor/trader, labor/social worker, not-working/wifehose and others employees $(\mathrm{p}=0.031)$. The patients who works as farmer/sailor/trader, labor/social worker, not-working/wifehose and others employees had higher recovery rate than nonrecovery rate. While the pateints who works as public/private employees had lower recovery rate than non-recovery rate.

TABLE 5. Comparison of recovery rate based on the occupation category

\begin{tabular}{lccc}
\hline Variables & Recover $(\mathrm{n}=83)$ & Non-Recover $(\mathrm{n}=83)$ & $\mathrm{p}$ \\
\hline Public/private employees & $11(39.3 \%)$ & $17(60.7 \%)$ & \\
Farmer/sailor/trader & $6(60.0 \%)$ & $4(40.0 \%)$ & \\
Labour/social worker & $119(67.9 \%)$ & $9(32.1 \%)$ & 0.031 \\
Not-working/wifehouse & $39(73.6 \%)$ & $14(26.4 \%)$ & \\
Others & $32(70.2 \%)$ & $14(29.8 \%)$ & \\
\hline
\end{tabular}

TABLE 6 shows the compariosn of recovery rate of patients based on the smooking activity. The smookin activity of patients did not influence the recovery rate of patients $(p=0.519)$. 
TABLE 6. Comparison of recovery rate based on smoking activity

\begin{tabular}{lccc}
\hline Variable & Recover (n 83) & Non-recover (n 83) & $\mathrm{p}$ \\
\hline Non-smoking, smoking person (-) at home & $32(64.0 \%)$ & $18(36.0 \%)$ & \\
Non-smoking, smoking person (+) at home & $55(67.1 \%)$ & $27(32.9 \%)$ & 0.519 \\
Smokes 1-9 cigarette per day & $16(69.6 \%)$ & $7(30.4 \%)$ & \\
Smokes 10-19 cigarette per day & $5(50.0 \%)$ & $5(5.00 \%)$ & \\
Smokes $>20$ cigarette per day & $0(0.0 \%)$ & $1(100.0 \%)$ & \\
\hline
\end{tabular}

\section{DISCUSSION}

In primary health care settings in Indonesia, ARTIs includes ARI is the most common diagnosis made by physicians. It is well known fact that these ARTIs are mostly caused by viral infections and self limiting, therefore antibiotics are most unnecessary. However, many evidences showed that most patients who are diagnosed ARTIs, antibiotics are prescribed regularly by physicians. ${ }^{9,10}$

This study shows that no significant differences in the recovery rate between the ARI patients who treated with antibiotics compared to without antibiotics $(\mathrm{p}=0.416)$. A study conducted by Orr et al. ${ }^{14}$ showed that antibiotics is not effective in the treatment of acute bronchitis. Another study conducted in the United States showed that although antibiotics have little or no benefit for colds URTIs or brochitis, however antibiotics have been prescribed by physicians. ${ }^{15}$ Furthermore, it was reported that antibiotics are commonly prescribed for patients with URTs even though they are usually ineffective. ${ }^{16}$

Many factors influence the overprescribing of antibiotics done by physicians. The physicians have been reported to prescribe antibiotics due to the perception that parents or patients want the antibiotics; however, this is not the main factor. The complex relationship between physicians and patients often leads to unnecessary antibiotic administration. Physicians in the primary health care tend to use broader spectrum antibiotics than considered necessary. ${ }^{17}$ The other factor in overprescribing of antibiotics is the prescribing habits of individual physicians coupled with the lack of self confidence and ignorance. ${ }^{18}$

This study also shows that the recovery rate of ARI patients is not influenced by gender differences and smoking activity; however, it is influenced significantly by job category. It is assumed that gender differences act as a risk factor for non-specific ARI. ${ }^{19}$ Male undergo exposure to smoke and fumes more often than female. Therefore, male patients more visit in primary health care than female patients due to URTIs. ${ }^{20}$ However, a study conducted in the United States reported that the recovery rate of URTIs patients is not associated with gender differences but it is associated with environment, age and nutritional status of the patients. $^{21}$

It has been reported that smoking is a risk factor for URTIs. Persons who smoke have the higher risk of URTIs, pneumonia and tuberculosis. Smoking is believed to exacerbate respiratory diseases by harming respiratory defense mechanisme. Burning a tobacco produces an aerosol of vaporized chemical and particulates that include nicotine, multiple carcinogens, oxidant and carbon monoxide. ${ }^{22}$ The physical properties of cigarette smoke promote the disposition of particle in thelower airways, where they affect respiratory defense mechanisme at multiple levels such as damages 
mucociliary function which impairs clearance of inhaled substances, promotes bacterial adherence to airway epithelial cells, ncreases alveolar vascular and epithelial permeability, affects the composition, appearance, and function of pulmonary inflammatory cells and reversibly depresses natural killer-cell function. ${ }^{23}$ Mercy and Merill ${ }^{24}$ reported that patients with non-specific ARI with exposure to smoke and fumes have a longer duration on recovery as long as they are smoking. Conversely, this study found that the recovery rate of ARI patients is not associated with smoking activity.

This study also found that the occupation category influences the recovery rate of ARI patients. The patients who works as farmer/ sailor/trader, labor/social worker, not-working/ wifehose and others employees had higher recovery rate, while the pateints who works as public/private employees had lower recovery rate. It was reported that physical activity influence immune function and as consequence risk of infections from the common cold and other URTIs. $^{25}$

\section{CONCLUSION}

In conclusion, the administration of antibiotic in ARI patients does not influence their recovery rate. Morover, smoking, age, and gender do not influence the recovery rate of ARI patients. However, the occupation category influenced the recovery rate. Efforts aimed at preventing the irrational use of antibiotics in ARI patients should be conducted to minimize the negative impact of antibiotic use.

\section{ACKNOWLEDGEMENTS}

This study was supported by a grant from Puskesmas Cilacap I, Cilacap District, Central Java. Authors would like to thank all clinical staff of Puskesmas Cilacap I for their valuable assistances during study.

\section{REFERENCES}

1. Pitrez PMC and Pitrez JLB. Acute upper respiratory tract infections: outpatient diagnosis and treatment J Pediatr (Rio J). 2003;79 (Suppl 1):S77-S86.

2. Cardozo DM, Nascimento-Carvalho CM, Andrade AL, Souza FR, Silva NM. The burden of acute nasopharyngitis among adolescents. Arch Dis Child. 2006; 91(12):1045.

3. Aymard M, Valette M, Luciani J, Sentinel Physicians from the Grippe et Infections Respiratoires Aiguës Pédiatriques Network. Burden of influenza in children: preliminary data from a pilot survey network on community diseases. Pediatr Infect Dis J. 2003; 22(10 Suppl):S211-4.

4. Counihan ME, Shay DK, Holman RC, Lowther SA, Anderson LJ. Human parainfluenza virusassociated hospitalizations among children less than five years of age in the United States. Pediatr Infect Dis J. 2001; 20(7): 646-53.

5. Anonim. Pedoman pemberantasan penyakit infeksi saluran pernapasan akut pada balita. Jakarta, Departemen Kesehatan Republik Indonesia: 2004.

6. Utami DP. Gambaran klinis dan faktor-faktor yang mempengaruhi angka kejadian ISPA pada Balita di Puskesmas Cimanggu 1 Kabupaten Cilacap [Skripsi]. Fakultas Kedokteran UII,Yogyakarta; 2011.

7. Widoyono. Penyakit tropis: Epidemiologi penularan pencegahan dan pemberantasannya. Jakarta. Penerbit Airlangga; 2008.

8. Harnden A, Perera R, Brueggemann AB, MayonWhite R, Crook DW, Thomson A, et al. Respiratory infections for which general practitioners consider prescribing an antibiotic: a prospective study. Arch Dis Child. 2007; 92(7):594-7.

9. Butler CC, Hood K, Verheij T, Little P, Mel bye $\mathrm{H}$, Nuttall $\mathrm{J}$, et al. Variation in antibiotic prescribing and its impact on recovery in patients with acute cough in primary care: prospective study in 13 countries. BMJ 2009, 338:b2242.

10. Mangione-Smith R, McGlynn EA, Elliott MN, McDonald L, Franz CE, Kravitz RL. Parent expectations for antibiotics, physician-parent 
communication, and satisfaction. Arch Pediatr Adolesc Med. 2001; 155:800-6.

11. Yagupsky P. Selection of antibiotic-resistant pathogens in the community. Pediatr Infect Dis J. 2006; 25:974-6.

12. Bauchner H, Pelton SI, Klein JO: Parents, physicians, and antibiotic use. Pediatrics. 1999; 103:395-8.

13. Melbye H, Aasebo U, Straume B. Symptomatic effect of inhaled fenoterol in acute bronchitis: a placebo-controlled double-blind study. Fam Pract. 1991;8:216-22.

14. Orr PH, Scherer K, Macdonald A, Moffatt ME. Randomized placebo controlled trials of antibiotics for acute bronchitis, A critical review of the literature. J Fam Pract. 1993;36(5):50712.

15. Gonzales R, Steiner JF, Sande MA. Antibiotic prescribing for adults with colds, upper respiratory tract infections, and bronchritis by ambulatory care physicians. JAM. 1997;278(11):901-4.

16. Stone S, Gonzales R, Maselli J, Lowenstein SR. Antibiotic prescribing for patients with colds, upper respiratory tract infections, and bronchitis: A national study of hospital-based emergency departments. Ann Emer Med. 2000;36(4):320-7.

17. Mangione-Smith R, McGlynn EA, Elliott MN, Krogstad P, Brook RH. The relationship between perceived parental expectations and pediatrician antimicrobial prescribing behavior. Pediatrics. 1999;103(4 Pt 1):711-8.

18. Kutty N. Treating children without antibiotics in primary health care. Oman Med J. 2011;26(5):3030-5.

19. Anzueto A and Niederman MS. Diagnosis and treatment of rhinovirus respiratory tract infections. Chest. 2003;123:1664-72.

20. van Gageldonk-Lafeber AB, Heijnen ML, Bartelds AI, Peters MF, van der Plas SM, Wilbrink B. A case-control study of acute respiratory tract infection in general practice patients in The Netherlands. Clin Infect Dis. 2005;41(4):490-7.

21. Tregoning JS and Schwarze J. Respiratory viral infections in infants: causes, clinical symptoms, virology, and immunology. Clin Microbiol Rev. 2010;23(1):74-98.

22. McCusker K. Mechanisms of respiratory tissue injury from cigarette smoking. Am J Med. 1992; 93(1A):18S-21S.

23. Murin S and Bilello KS. Respiratory tract infection another reason not to smoke. Clev Clin J Med. 2007;72(10): 916-7.

24. Mercy TW and Merrill WW. Cigarette smoking and respiratory tract infection. Clin Chest Med. 1987;8(3):381-91.

25. Neiman DS. Does exercise alter immune function and respiratory infections? Res Digest. 2001; $3(13): 1-6$. 